\title{
Correction to "Antidepressant Potential of (R)-Ketamine in Rodent Models: Comparison with (S)-Ketamine"
}

\begin{abstract}
The authors of the above article [Fukumoto K, Toki H, Iijima M, Hashihayata T, Yamaguchi J, Hashimoto K, and Chaki S (2017) J Pharmacol Exp Ther 361(1):9-16; DOI: https://doi.org/ 10.1124/jpet.116.239228] failed to note that Fig. 1(C) was reproduced from Fukumoto K, Iijima M, and Chaki S (2016) The Antidepressant Effects of an mGlu2/3 Receptor Antagonist and Ketamine Require AMPA Receptor Stimulation in the $\mathrm{mPFC}$ and Subsequent Activation of the 5-HT Neurons in the DRN. [Neuropsychopharmacology 41:1046-1056; DOI: 10.1038/npp.2015.233.] The source of the image should have been cited.
\end{abstract}

The authors regret this error and apologize for any inconvenience it may have caused. 